\title{
„WIE IN UNSEREN ERBLÄNDERN“- KRAJIŠKA PRAVA (1754.) U KONTEKSTU CENTRALIZACIJE I MODERNIZACIJE U VOJNOJ KRAJINI
}

\author{
Marko Petrak \\ Kristina Milković Šarić
}

UDK: 34(497.5-3 Vojna krajina)“17/18“"

Sažetak: Cilj rada analizirati je nastanak, strukturu i značenje Krajiških prava iz 1754. g. kao temeljnog propisa iz razdoblja carice Marije Terezije za Vojnu krajinu. Autori zaključuju da je osnovna svrha navedenog propisa bila unificirati i modernizirati pravni sustav u Vojnoj krajini te ga, kolikogod je to moguće, harmonizirati s pravnim sustavom u nasljednim zemljama Monarhije („...wie in Unseren Erbländern..."). Autori Krajiških prava „transplantirali“ su, barem kad je riječ o normativnoj razini, čitava uređenja temeljnih pravnih grana iz nasljednih zemalja Monarhije u analfabetska krajiška društva kojima je bilo zajedničko da je njihova svakodnevica dotad uglavnom bila regulirana pravilima običajnog prava. Posebno značenje pri ostvarenju navedenih ciljeva imalo je ius commune kao recipirano rimsko pravo. Međutim, usprkos svoje istaknute prosvjetiteljske usmjerenosti, autori propisa, polazeći od interesa države, bili su ipak u određenoj mjeri svjesni da krajiško društvo nije tabula rasa te da u regulaciji pojedinih pravnih materija treba voditi računa i o postojećem lokalnom stanju. Time su stvoreni preduvjeti kako za susret, tako i za konflikt različitih pravnih kultura u složenim odnosima između središta i periferije Monarhije.

Ključne riječi: Krajiška prava, Vojna krajina, pravna povijest, rimsko pravo, Marija Terezija

\section{Uvodne napomene}

zv. Krajiška prava (punim nazivom MILITAR Gränitz-Rechten Von Ihro Kaiserl. Königl. Majestät Für das Carlstädter- Und Varasdiner - Generalat Vorgeschrieben im Jahr 1754.) pravni su propis tiskan na njemačkome jeziku kao posebna knjižica ${ }^{1}$. Tekst

\footnotetext{
Navedeni pravni propis se u našoj historiografiji uobičajeno naziva Krajiška prava. Poštujući tradiciju, navedeni naziv zadržan je i u ovom radu, no treba napomenuti da pojam „prava“ u navedenom izrazu treba shvatiti isključivo u objektivnom smislu (u značenju skupa pravnih normi), a ne u subjektivnom smislu (u značenju osobnih ili kolektivnih ovlaštenja). Tekst Krajiških prava pretiskan je u cjelosti u sljedećem zborniku propisa: Ignaz DE LUCA, Iustitzcodex, Bd. II, Wien 1793, 231-361, dostupnom na internetskoj adresi http://books.google.hr/books/about/Iustitzcodex.html
} 
je tiskan frakturom, njemačkim kurentnim pismom, koje je dominiralo na njemačkom govornom prostoru od 16. sve do 20. stoljeća. ${ }^{2}$ Osim frakture javlja se i antikva, latinski humanistički kurziv koji se u tiskanim tekstovima rabio za sve strane riječi. U tekstu Krajiških prava antikvom su tiskani pojmovi recipiranog rimskoga prava (ius commune) te germanizirane latinske riječi u kojima je korijen riječi pisan antikvom, a nastavci frakturom. Već je na prvi pogled uočljivo da je čitav tekst prošaran antikvom što na svoj način dovoljno svjedoči o prisutnosti latinskoga jezika u njemu. Knjižica je tiskana u Beču 1754. godine kod dvorskoga tiskara Johanna Petera Ghelena. Sadržava 126 nepaginiranih stranica, jednu ilustraciju s prikazom tzv. Bamberške sprave i primjer formulara koje su skrbnici o pupilima i njihovim dobrima, koji su im bili povjereni, morali podnosti svake godine Dvorskome ratnom vijeću.

Tekst Krajiških prava, s ukupno 394 zakonska članka, podijeljen je na sedam titula:

1. Titulus I. (11 članaka)

Von denen Gesätzen, nach welchen die Gränitz-Trouppen in dene Carlstädter- und Varasdiner-Generalaten zu leben, und die Gerichter zu sprechen haben.

O zakonima prema kojima u Karlovačkom i Varaždinskom Generalatu krajiške postrojbe trebaju živjeti, a sudovi odlučivati

Titulus II. (22 članka)

Von denen Militar-Gränitz-Gerichtern, und Jurisdiction.

$\mathrm{O}$ vojnokrajiškim sudovima i jurisdikciji

Titulus III. (66 članaka)

Von dem Civil-Process, wie solcher bey Unseren Militar-Gränitz-Gerichtern abzuführen? O građanskom postupku: kako ga voditi na Našim vojnokrajiškim sudovima

Titulus IV. (88 članaka)

Von denen Grundstücken, und Militär-Gränitz-Lehen.

O zemljišnim dobrima i vojnokrajiškim lenima

Titulus $V$. (38 članaka)

Von letzten Willen, Erbfolge ab intestato Verlassenschafts-Abhandlungen, Pupillen, und Gerhaben.

O oporukama, zakonskom nasljeđivanju, ostavinskim raspravama, pupilima i skrbnicima Titulus VI. (69 članaka)

Von dem Criminal-Process.

O kaznenom postupku

Titulus VII. (100 članaka)

Tax-Ordnung, von die Regiments- und ober-Gerichte des Carlstädter- und Varasdiner-Generalats, und zwar: Für die Regiments-Gerichte.

Red pristojbi za pukovnijske i više sudove Karlovačkoga i Varaždinskoga generalata, napose za pukovnijske sudove

Kada su objavljena 1754. godine, Krajiška prava su isprva vrijedila samo za prostor Varaždinskoga i Karlovačkoga generalata, a tek od 1769. godine su uvedena na prostoru Slavonske i Banske krajine. ${ }^{3}$ Opravdano je stanovište austrijskoga povjesničara Karla Kasera da su Krajiška prava „koja su - budući da su se različite pravne norme dijelova krajine svodile

\footnotetext{
Sanja LAZANIN, Priručnik iz njemačke paleografije, Zagreb 2004.

3 Karl KASER, Slobodan seljak i vojnik. Povojačenje agrarnog društva u Hrvatsko-slavonskoj Vojnoj krajini (1535.-1881), Sv. II., Zagreb 1997, 22.
} 
na jedno jedino pravo - postala prijelomnim izrazom mnoštva promjena.“4 Ona, prema njegovu tumačenju, odražavaju težnju za unifikacijom i centralizacijom krajiškoga prostora i društva. Pomalo iznenađuje činjenica što su se habsburški zakonodavci najprije odlučili za uvođenje novoga pravnog sustava u tzv. „starim krajinama“ jer je ondje, za razliku od „novih krajina“ gdje se i u zakonodavnome smislu moglo krenuti ab ovo, postojao niz pravnih normi i praksi koje je trebalo uzeti u obzir.

Preduvjeti za tako snažan izraz dvorske moći bili su stvoreni teritorijalnim dobicima u habsburško-osmanskome ratu (1683.-1699.) tijekom kojega su Habsburgovci uspjeli potisnuti Osmanlije s prostora Like i Krbave te iz Slavonije. Također su bili stvoreni institucionalni preduvjeti. Od početka 18. stoljeća sužavane su ovlasti koje je imalo Dvorsko ratno vijeće u Grazu, a preko njega unutrašnjoaustrijski staleži, a potom je bilo i ukinuto. Nakon kratkotrajnog djelovanja Vojnoga direktorija, sva vlast koncentrirana je na jednome mjestu, Dvorskome ratnom vijeću u Beču kao centralnoj instituciji. Istodobno se hrvatsko plemstvo suglasilo da se Banska krajina, koja je u spomenutom ratu proširena na područje između rijeka Kupe i Une, ustroji po uzoru na ostatak krajine i podredi Dvorskome ratnom vijeću. Vlastelinstava praktički na krajiškim teritorijima više nije bilo, a s njima je nestalo i pravne strukture. Reforme prve polovice 18. stoljeća u Vojnoj krajini, i Krajiška prava kao njihov sastavni dio, bile su rezultat nadmoći dvora nad unutrašnjoaustrijskim i hrvatskim plemstvom te je dvorska hijerarhija praktički neovisno odlučivala o budućem ustroju Krajine.

\section{Krajiška prava - između centralizacijskih „transplanata“ i lokalnih posebnosti}

Nastanak ovog pravnog propisa vezan je prije svega uz proces kodifikacije zakona u Habsburškoj Monarhiji u širem kontekstu centralizacijsko-prosvjetiteljskih reformi i djelo je stručno-profesionalnoga kruga, obrazovanih pravnika. To je u punom smislu riječi bila habsburška reforma „odozgo“. Ona je uistinu, kako je to interpretirao K. Kaser, predstavljala cezuru u vojnokrajiškoj povijesti premda se tijekom prve polovice 18. stoljeća nastojalo urediti pojedine dijelove Krajine posebnim aktima - regulamentima u kojima su već djelomično anticipirana neka pravna rješenja koja će konačno biti donešena Krajiškim pravima.

Za adekvatnu ilustraciju navedene ambicije centralizacije i prosvjetiteljske modernizacije pravnog sustava u kontekstu Vojne krajine, što se nastojalo provesti „pravnim transplantima" cjelokupnih temeljnih pravnih grana iz središta Monarhije na njenu krajnju periferijus, možda je ponajbolje detaljnije raščlaniti odredbe Tit. I. \$\$ 5-7 Krajiških prava. Te odredbe sadrže precizne normativne upute o tome koje će se pravne norme primjenjivati kao ius in subsidio na području Vojne krajine u sferi kaznenog prava (\$\$ 5-6) i građanskog prava (\$ 7$)$ glede svih onih pravnih odnosa koji nisu izravno i detaljno regulirani samim paragrafima Krajiških prava. Drugim riječima, spomenute odredbe iscrpno navode različite opće pravne izvore koji će se u Vojnoj krajini primijeniti kao važeće pravo u svim onim slučajevima u kojima sama Krajiška prava, bivajući prima facie propis za određeno vojno područje, ne sadrže vlastite pravne norme koje uređuju navedene temeljne pravne grane.

Isto, 7.

O teoriji pravnih transplanata u suvremenoj znanosti pravne povijesti i komparativnog prava v. Dalibor ČEPULO, „Tradicija i modernizacija: „iritantnost“ Općeg građanskog zakonika u hrvatskom pravnom sustavu“, u: Liber amicorum Nikola Gavella, Zagreb, 2007, 3-5, s uputama na daljnju literaturu. 


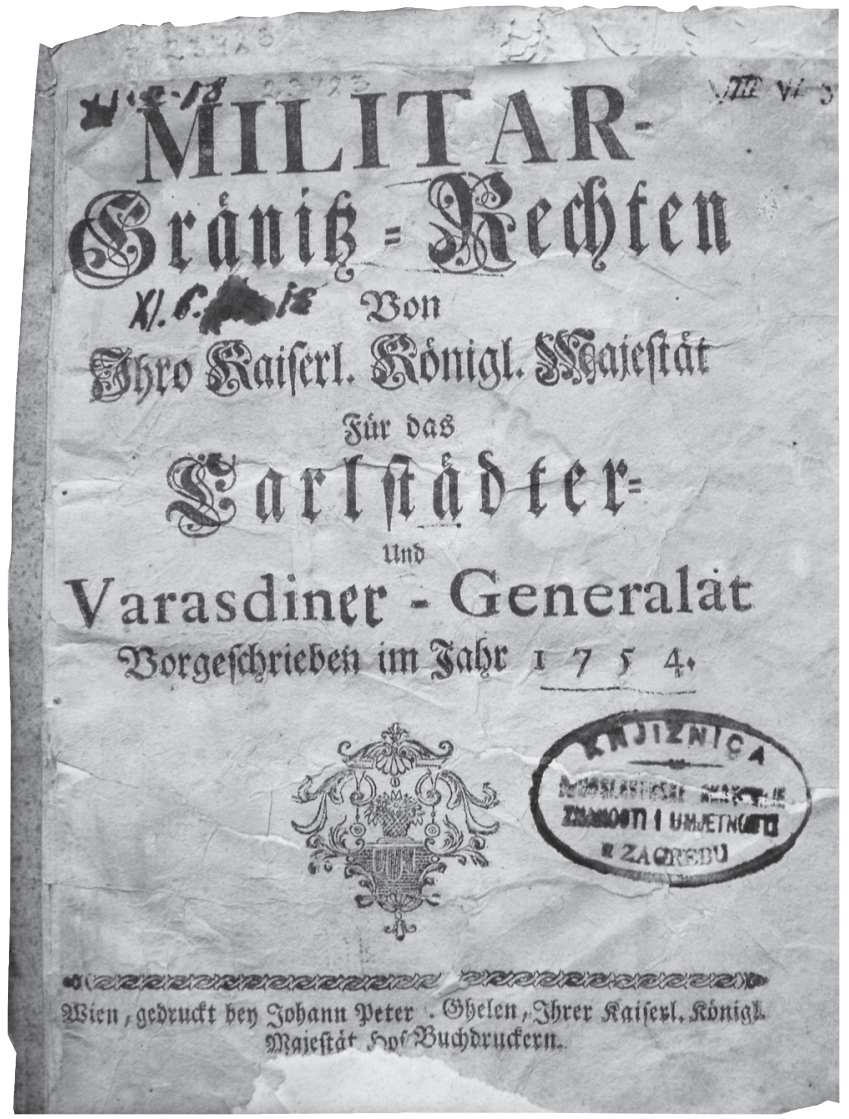

Militargränitz-Rechten... (Beč, 1754.)

Ukratko će se raščlaniti pitanje koji su opći izvori kaznenog prava i građanskog prava postali na taj način sastavnim dijelom pravnog sustava Vojne krajine, sukladno odredbama Tit. I. \$\$ 5-7 Krajiških prava. Nakon provedene raščlambe, pokušat će se zaključiti kakve su se promjene i učinci nastojali postići navedenom pravnom inovacijom.

Izvori kaznenog prava koji će se primjeniti u Vojnoj krajini navedeni su u Tit. I. $\$ \$ 5-6$ Krajiških prava. Odredba koji sadrži Tit. I. $\$ 5$ razlikuje ponajprije u navedenom pogledu opće kazneno pravo od specifično vojnog kaznenog prava (,....in peinlichen Sachen in delictis communibus, seu non militaribus..." $)^{6}$.

U pogledu općeg kaznenog prava, Tit. I. $\$ 5$ određuje da su kaznenopravni izvori u Vojnoj Krajini isti oni koji vrijede u nasljednim zemljama Monarhije (,...wie solche in Unsern Teutschen Erbländern..."). Riječ je o sljedećim temeljnim kaznenim propisima: Constitutio criminalis Carolina cara Karla V. iz 1532. g.; Constitutio criminalis Ferdinandea cara Ferdinanda III. iz 1656. g. te Constitutio criminalis Josephina cara Josipa I. iz 1707. g. ${ }^{7}$

\footnotetext{
O razlici između općih kaznenih djela (delictum commune) i vojnih kaznenih djela (delictum militare) u kontekstu pravnog sustava Vojne krajine v. Alexander BUCZYNSKI, „Organizacija policije i pravosuđa u Vojnoj krajini“, Povijesni prilozi, 13/1994, 94-95.

7 Općenito o navedenim propisima (Carolina, Ferdinandea, Josephina) i njihovim obiljě̌jima u kontekstu razvoja kaznenog prava u nasljednim zemljama Monarhije v. prije svega Ernst C. HELLBLING, Grundlegende Strafrechtsquellen der österreichischen Erbländer von Beginn der Neuzeit bis zur Theresiana. Ein Beitrag zur Geschichte des Strafrechts in Österreich, Wien-Köln-Weimar, 1996; usp. i Vladimir BAYER, Kazneno procesno pravo - odabrana poglavlja, knjiga
} 
Premda to nije izričito navedeno u $\$ 5$ Krajiških prava, supsidijarni izvor kaznenog prava mogao je biti - kao i u nasljednim zemljama Monarhije - ius commune ${ }^{8}$, odnosno, riječima same carice Marije Terezije, Römerrecht $\mathrm{u}$ smislu recipiranog rimskog prava9 ${ }^{9}$ Na to bi posredno ukazivala i činjenica da je u Tit. VI. Krajiških prava (\$ 19), koji inače uređuje kazneni postupak, navedena i kaznenopravna doktrina (bewehrte Criminalisten) kao jedan od mogućih izvora prava. Kako je u to doba ius commune bio glavni temelj pravne znanosti u Europi, samorazumljivo je da su kaznenopravni Authores und Commentarii, koje spominje Tit. VI \$ 19, bili u najvećoj mjeri nadahnuti tradicijom općeg prava (ius commune), njenim načelima, institutima i konkretnim rješenjima ${ }^{10}$.

Samom pojmu općeg prava (ius commune) vratit ćemo se uskoro pri raščlambi građanskopravnih izvora u Krajiškim pravima, budući da je, kako je opće poznato, recepcija rimske pravne kulture u Europi bila još intenzivnija u sferi privatnog prava. Glede pitanja kaznenopravnih izvora u Krajiškim pravima, pak, preostalo je osvrnuti se na pitanje izvora vojnog kaznenog prava. Razmatrajući tome posvećen Tit. I. $\$ 6$ u vezi sa već spomenutim Tit. VI $\$ 19$ moglo bi se zaključiti da se kao primarno pravo imaju primjeniti vojni propisi Monarhije, prije svega tzv. ratni članci (Kriegsartikel), potom spomenuti opći kazneni propisi Carolina, Ferdinandea i Josephina, nakon toga običajno pravo (hergebrachte Gewohnheiten) te naposljetku kaznenopravna doktrina (bewehrte Criminalisten) ${ }^{11}$.

Navedeno uređenje izvora kaznenog prava u Vojnoj krajini zadržano je sve do 1768. g., kada je donesena znamenita Constitutio criminalis Theresiana kao nova kaznenopravna kodifikacija. Zanimljivo je spomenuti da je još $1767 \mathrm{~g}$. Državno vijeće (Staatsrat) istaknulo da je u Vojnoj krajini glavni kaznenopravni izvor Ferdinandea, osim u situacijama kada ratni članci (Kriegsartikel) u pogledu vojnopravne materije sadrže odredbe drukčijeg sadržaja ${ }^{12}$. Sve u svemu, ako se ima u vidu do sada navedene činjenice, može se zaključiti da su norme Krajiških prava u pogledu formalnih izvora kaznenog prava nastojale harmonizirati pravni sustav Vojne krajine s kaznenim pravom nasljednih zemalja Monarhije u mjeri u kojoj je to bilo moguće obzirom na sve specifičnosti tog prostora. Pored navedene vrste centralizacije, nedvojbeno je izvršena i određena modernizacija pravnih izvora, budući da je krajiška kaznenopravna praksa morala uzimati u obzir i recentnije pravne propise i doktrinu. No time se ujedno kaznenopravni sustav Vojne krajine u pogledu pravnih izvora počeo udaljavati od sustava Banske Hrvatske u kojoj je prevladavalo običajno kazneno pravo ${ }^{13}$. To je udaljavanje

II, Povijesni razvoj kaznenog procesnog prava, Zagreb, 1995, 61-78; Rudolf HOKE, Österreichische und deutsche Rechtsgeschichte, Wien-Köln-Weimar, 1996, 424-431; na navedenu problematiku kaznenopravnih izvora u kontekstu Krajiških prava sasvim kratko se osvrnuo i Alfonz DOMIN PETRUŠEVEČKI (Alphons von Domin-Petrushevecz) u svom važnom djelu Neuere österreichische Rechtsgeschichte, Wien, 1869, 42.

8 O ius commune kao supsidijarnom izvoru kaznenog prava u Carstvu v. Ernest v. KWIATKOWSKI, Constitutio criminalis Theresiana. Ein Beitrag zur theresianischen Reichs- und Rechtsgeschichte, Innsbruck 1904, 17-18.

9 Carica Marija Terezija uporabila je izraz Römerrecht za ius commune kao recipirano rimsko pravo u reskriptu od 31. prosinca 1768. g. kojim je Constitutio criminalis Theresiana stupio na snagu, opisujući dotadašnje vrlo složeno i partikularizirano stanje kaznenopravnih izvora u Carstvu, koje je ona namjeravala okončati tom novom kaznenopravnom kodifikacijom; v. tekst reskripta u: KWIATKOWSKI, Constitutio criminalis Theresiana, 15, bilj. 2.; općenito o recepciji rimskog prava u kaznenopravnoj sferi v. BAYER, Kazneno procesno pravo, 59-72.

10 O ius commune i kaznenopravnoj doktrini u 18. stoljeću v. npr. Nella LONZA, Pod plaštem pravde, Kaznenopravni sustav Dubrovačke republike u XVIII st., Dubrovnik, 1997, 25-35, s uputama na daljnju literaturu.

11 Usp. DOMIN-PETRUSHEVECZ, Neuere österreichische Rechtsgeschichte, 42; Ivan BEUC, Povijest institucija državne vlasti Kraljevine Hrvatske, Slavonije i Dalmacije, Zagreb, 1985, 230.

12 ,....Auch in den Carlstädter und Warasdiner Militär-Gräniz-Distrikten wird die Ferdinandea beobachtet, in so weit quoad militare die Kriegsartikel nicht etwas anderes statuiren" (St. R. 245./ 1767.); cit. prema KWIATKOWSKI, Constitutio criminalis Theresiana, 15-16, bilj. 3 .

13 Ipak, odredbe Krajiških prava dovele su prije svega do udaljavanja dva pravna sustava na razini formalnih izvora kaznenog prava. Sadržajno gledano, pak, treba istaknuti da se od navedenih izvora Ferdinandea primjenjivala i u 
dovršeno 1768. g. kada je donesena Constitutio criminalis Theresiana. Naime, navedena kodifikacija, kojom je provedena odlučna modernizacija i unifikacija kaznenog prava u nasljednim zemljama Monarhije ${ }^{14}$, odmah je stupila na snagu i u Vojnoj krajini, za razliku od Banske Hrvatske u kojoj je nastavio vrijediti dotadašnji predmoderni kaznenopravni poredak ${ }^{15}$.

Situacija sa građanskopravnim izvorima u Krajiškim pravima bila je u određenoj mjeri jednostavnija. Naime, Tit. I. $\$ 7$ lapidarno određuje da će izvor građanskog prava u Vojnoj krajini biti ,...die allgemeine geschriebene Rechten, wie solche in Unseren Erbländern recipiret...", dakle, opće pisano pravo recipirano u nasljednim zemljama Monarhije, osim ako Krajiška prava određeni pravni odnos ne uređuju drukčije. Postavlja se pitanje što bi u navedenom kontekstu trebala značiti sintagma „opće recipirano pisano pravo"? Alfonz pl. Domin Petruševečki je 1869. g. smatrao da je u Tit. I. \$ 7 riječ o recipiranom općem pravu (,...nach dem recipirten gemeinen Rechte..." ${ }^{16}$. Današnja znanost rimskog prava, pak, zastupa u širem kontekstu analize fenomena recepcije u nasljednim zemljama Monarhije identično shvaćanje, ističući da se pojam geschriebene Rechte odnosi na opće pravo (ius commune) u suprotnosti, primjerice, $s$ nepisanim običajnim pravom ${ }^{17}$. Stoga treba zaključiti da sintagma citirana u Tit. I. $\$ 7$ Krajiških prava nedvojbeno označava ius commune kao recipirano rimsko pravo.

Premda smo pojam ius commune već spominjali, na ovom će ga mjestu biti najprikladnije sažeto odrediti. Sasvim ukratko i nedostatno rečeno, pojam ius commune označava pravni sustav koji je vrijedio u gotovo čitavoj Europi u kasnom srednjovjekovnom i ranonovovjekovnom razdoblju. Taj je sustav oblikovan recepcijom rimskog prava, tj. procesom postupnog preuzimanja pravila rimskog prava sadržanog u Justinijanovoj kodifikaciji (Corpus iuris civilis) kao pozitivnog prava, uz prilagodbu tih pravila potrebama života i pravne prakse navedenih razdoblja te njihovog povezivanja s pojedinim elementima kanonskog prava $i$ običajnih prava. Ius commune kao recipirano rimsko pravo primjenjivalo se kao supsidijarni pravni izvor (ius in subsidio) na sve one pravne slučajeve koji nisu bili regulirani partikularnim pravom, a taj je prostor bio znatan, posebice u privatnopravnoj sferi ${ }^{18}$. $U$ nasljednim zemljama Monarhije, recepcija rimskog prava kao općeg prava bila je posebice intenzivna u razdoblju od 16. do 18. stoljeća, što je u novije vrijeme uzorno i iscrpno istražio gradački romanist Gunter Wesener, na čije radove ovdje upućujemo ${ }^{19}$. Tome nasuprot, u zemljama

zemljama krune sv. Stjepana, pa tako i u Banskoj Hrvatskoj. No za razliku od Vojne krajine, Ferdinandea nije u zemljama krune sv. Stjepana imala status državnog propisa, već je prihvaćena običajnim putem, na način da je pod nazivom Praxis Criminalis uvrštena u izdanje Corpus iuris Hungarici iz 1696. g.; o recepciji Constitutio criminalis Ferdinandea kao običajnog prava u ugarsko-hrvatskom pravnom sustavu v. Gábor BÉLI - Marko PETRAK - Nikol ŽIHA, „Corpus iuris civilis i Corpus iuris Hungarici. Utjecaj rimske pravne tradicije na ugarsko-hrvatsko pravo“, in: Mirela ŽUPAN - Mario VINKOVIĆ (eds.), Suvremeni pravni izazovi: EU - Madarska - Hrvatska, Pečuh - Osijek, 2012, 69-70.

14 Detaljnije o donošenju i obilježjima terezijanske kaznenopravne kodifikacije v. KWIATKOWSKI, Constitutio criminalis Theresiana; Egmont FOREGGER, Constitutio criminalis Theresiana, Graz, 1993, 3-30.

15 Usp. npr. Dalibor ČEPULO, Hrvatska pravna povijest u europskom kontekstu, Zagreb, 2012, 129.

16 DOMIN-PETRUSHEVECZ, Neuere österreichische Rechtsgeschichte, 42.

17 O pojmu geschriebene Rechte u navedenom kontekstu v. detaljnije Gunter WESENER, Einflüsse und Geltung des römisch-gemeinen Rechts in den altösterreichischen Ländern in der Neuzeit (16. bis 18. Jahrhundert), Wien - Köln, 1989, 16-30; Marko KAMBIČ, Recepcija rimskega dednega prava na Slovenskem s posebnim ozirom na dedni red Karla VI., Ljubljana, 2007, 37.

18 Općenito o ius commune kao pravnom sustavu v. npr. Francesco CALASSO, Introduzione al diritto commune, Milano, 1970; Helmut COING, Die ursprüngliche Einheit der europäischen Rechtswissenschaft, Wiesbaden, 1968; idem, Europäische Grundlagen des modernen Privatrechts, Opladen, 1986; Manlio BELLOMO, L'Europa del diritto comune, Roma, 1998; Raoul VAN CAENEGEM, European Law in the Past and the Future, Cambridge, 2002.

19 V. prije svega WESENEROVU sintezu „Einflüsse und Geltung des römisch-gemeinen Rechts in den altösterreichischen Ländern in der Neuzeit (16. bis 18. Jahrhundert)", Wien - Köln, 1989, s uputama na brojnu daljnju literaturu o navedenoj problematici. 
krune sv. Stjepana, pa tako i u Banskoj Hrvatskoj, privatno pravo je u 18. st. bilo još uvijek ponajprije utemeljeno na Werböczyevu Tripartitu iz 1514. g. kao neozakonjenom zborniku tradicionalnog ugarsko-hrvatskog običajnog prava, u kojem nije moguće pronaći dublje tragove rimske pravne kulture ${ }^{20}$. Stoga je navedenom odredbom Krajiških prava o izvorima građanskog prava, carica Marija Terezija nastojala i građanskopravni segment pravnog sustava Vojne krajine harmonizirati sa sustavom rimskog privatnog prava recipiranog $\mathrm{u}$ nasljednim zemljama Monarhije (,...wie solche in Unseren Erbländern recipiret...“) u mjeri u kojoj je to bilo moguće. Dominantan smjer teorijske i praktične obrade rimskog prava u Europi u to je doba predstavljao tzv. usus modernus Pandectarum kao osuvremenjujuća interpretacija rimskih pravnih izvora (prije svega Justinijanovih Pandekata) u skladu s potrebama tadašnjeg vremena, utemeljena na načelima privatnog vlasništva, slobode ugovaranja i slobode oporučnog raspolaganja ${ }^{21}$. Stoga nije teško zaključiti da bi uvođenje takve inovirane forme rimske pravne kulture u Vojnu krajinu neizbježno rezultiralo intenzivnom individualizacijom i modernizacijom cjelokupnog privatnopravnog života u suprotnosti sa do tada postojećim različitim kolektivitetnim i tradicionalnim pravnim strukturama. Valja podvući i da se navedenom reformom, gledano s aspekta građanskopravnih izvora, Vojna krajina sasvim udaljila od Banske Hrvatske kao svog formalnog središta, koje će još gotovo cijelo stoljeće ostati u krugu predmodernog običajnog privatnog prava ${ }^{22}$.

Kako bi slika o građanskopravnim izvorima bila upotpunjena, treba spomenuti da pojedine odredbe Krajiških prava određuju da će - uz ius commune kao temeljni izvor - i pojedini posebni građanskopravni propisi nasljednih zemalja Monarhije biti pravo na snazi u Vojnoj krajini. Tako se, sukladno, Tit. V. \$18, glede pupilarne i skrbničke materije treba primijeniti Pupilarni red (Gerhabschaftsordnung) cara Leopolda I. iz 1669 g., dok je glede materije zakonskog nasljednog prava, sukladno Tit. V. $\$ 12$, pravni izvor postao Nasljedni red (Successionsordnung) cara Karla VI. iz 1721. $\mathrm{g}^{23}$. Navedeni nasljednopravni propis u najvećoj mjeri počiva na rimskoj pravnoj tradiciji, što je problematika koju je u najnovije vrijeme na iscrpan način istražio ljubljanski romanist Marko Kambič u svojoj primjernoj monografiji o recepciji rimskog nasljednog prava u slovenskim zemljama ${ }^{24}$.

Zaokružujući ovu kratku raščlambu prisutnosti rimske privatnopravne tradicije u pravnom sustavu uspostavljenom Krajiškim pravima, valja istaknuti kako je već na prvi pogled više nego razvidan intenzivan utjecaj navedene pravne tradicije, poglavito na uređenje civilnog procesa (Tit. III) te na nasljednopravno uređenje (Tit. V.). Također, gledajući s aspekta pravne terminologije, treba napomenuti da je tekst propisa kao djelo obrazovanih pravnika pun stručnih pravnih pojmova pripadnih rimskoj pravnoj kulturi te da je kao takav bio teško dostupan laiku. Bio je gotovo nepropustan za jezike krajiškoga stanovništva pa je u njemu našlo svoje mjesto tek nekoliko izraza (primjerice Prezemlaken - bezzemljaši, Mustuluck muštuluk, u značenju doušnička plaća). No to su zahvalne teme za neko buduće istraživanje.

20 O problematici (ne)recepcije rimske pravne tradicije u tradicionalnom ugarsko-hrvatskom pravu do 19 . stoljeća v. detaljnije BÉLI - PETRAK - ŽIHA, Corpus iuris civilis i Corpus iuris Hungarici, 59-76, s uputama na daljnju literaturu.

21 Općenito o usus modernus Pandectarum u Europi v. Franz WIEACKER, Privatrechtsgeschichte der Neuzeit, Göttingen, 1967, 204-248; specifično o usus modernus Pandectarum u nasljednim zemljama Monarhije v. Gunter WESENER, „Die Rolle des Usus modernus pandectarum im Entwurf des Codex Theresianus. Zur Wirkungsgeschichte des älteren gemeinen Rechts", u: Gerhard KÖBLER - Hermann NEHLSEN (eds.), Wirkungen europäischer Rechtskultur. Festschrift für Karl Kroeschell zum 70. Geburtstag, München, 1995, 1365-1388.

22 O tradiciji i modernizaciji privatnog prava u Banskoj Hrvatskoj v. ČEPULO, Tradicija i modernizacija, 1-50.

23 Usp. DOMIN-PETRUSHEVECZ, Neuere österreichische Rechtsgeschichte, 44; BEUC, Povijest institucija, 230.

24 V. KAMBIČ, Recepcija rimskega dednega prava, 119-212. 
Sve u svemu, može se zaključiti da je svrha upućivanja na opće izvore kaznenog i građanskog prava u Krajiškim pravima bila unificirati i modernizirati pravni sustav u Vojnoj krajini te ga - kolikogod je to moguće - harmonizirati s pravnim sustavom u nasljednim zemljama Monarhije (,....wie in Unseren Erbländern..."). Posebno značenje pri ostvarenju navedenih ciljeva imalo je ius commune kao recipirano rimsko pravo. Time je postavka da je „u 18. stoljeću rimsko pravo postalo elementom velikog duhovnog pokreta prosvjetiteljstva" ${ }^{25}$ dokazana u jednom konkretnom lokalnom slučaju. No u početnim odredbama Krajiških prava, primjerice Tit. I. $\$ 1$ i $\$ 8$, naići ćemo i na najviši pravni ideal prosvjetiteljstva: naravno pravo (Naturrecht) utemeljeno na zdravom razumu (die gesunde Vernunft) kao vrhovnom izvoru zamišljenog modernog pravnog sustava ${ }^{26}$.

Kako je opće poznato, svaka prosvjetiteljska reforma „odozgo“, pogotovo ako je počivala na naravnom pravu kao sredstvu „zdravorazumske modernizacije“, bila je kritički usmjerena prema zatečenim lokalnim posebnostima. Povrh toga, autori Krajiških prava su u odnosu na krajiško stanovništvo bili stranci ne samo u etničkome nego i u sociokulturnome smislu. Međutim, usprkos svoje prosvjetiteljske revnosti, bili su ipak u određenoj mjeri svjesni da krajiško društvo nije tabula rasa te da u regulaciji pojedinih pravnih materija treba voditi računa o postojećem lokalnom stanju.

Navedeno uzimanje u obzir postojećih krajiških okolnosti posebice je došlo do izražaja pri normativnom oblikovanju Tit. IV. kojim je uređen pravni režim zemljišnih dobara i lena u Vojnoj krajini. Kako se pri regulaciji spomenute materije nije moglo osloniti na metodu „pravnih transplanata“ iz nasljednih zemalja Monarhije, to je uređenje predstavljalo svojevrsni novum.

Stoga ne iznenađuje činjenica da se upravo Tit. IV. nalazi u prvome planu kad je riječ o historiografiji. Središnjost tog titula u interpretacijama povjesničara implicitno se nametnula budući da se pozornost uglavnom koncentrirala na pravnu definiciju zemljišta na koje imaju pravo krajišnici. Iz perspektive dvora, ali i iz perspektive stanovnika Krajine - krajišnika, zemlja je bila najvažnije pitanje. To je načelo bilo i eksplicitno izneseno na početku Tit. IV. („Die Grund-Stücke seynd wohl der wichtigste Gegenstand bey der Militar-Gränitz-Einrichtung ..."). Logika prema kojoj se Dvor ravnao u odnosu prema krajiškim zemljišnim dobrima bila je vrlo jednostavna: što se veći broj ljudi mogao izdržavati sa zemlje, to se većemu vojnom kontigentu mogla nadati carska kuća (,je mehr Volk davon erhalten wird, je mehr taugliche Mannschaft kan zu Unseren Kriegs-Diensten gestellt werden“). Dakle, člankom prvim Četvrtoga titula sva zemlja u Krajini je bila proglašena carskim lenom koje krajišnici imaju pravo slobodno koristiti, a zauzvrat su bili dužni obnašati vojnu službu unutar i izvan zemlje. Iz perspektive krajišnika, koji su živjeli u seljačkome društvu, pitanje korištenja zemljišnih dobara imalo je također najveće značenje.

Pitanje korištenja zemljišnih dobara bilo je uređeno velikim brojem članaka, a njima su obuhvaćene pravne okolnosti koje su se na krajiškom teritoriju javljale u posljednjih dvadeset godina. Titulom IV. se, zapravo, nastojalo uvesti red u postojeće stanje.

Odredbe članaka imale su podjednak utjecaj na „običan“ krajiški puk i na tradicionalne krajiške prvake knezove, vojvode i domaće časnike (Innländliche Officiere), koji su se ekonomski i socijalno izdvajali od grupe stranih časnika u Krajini.

$\overline{25}$ Cit. Peter Stein, Rimsko pravo i Europa. Povijest jedne pravne kulture, Zagreb, 2007, 123.

26 O naravnom pravu u kontekstu kodifikacijskih pothvata carice Marije Terezije v. npr. STEIN, Rimsko pravo i Europa, 126-127; Srđan ŠARKIĆ - Dragoljub POPOVIĆ, Veliki pravni sistemi i kodifikacije, Beograd, 2005, 130-138, s uputama na daljnju literaturu. 
Terminologija koja se odnosi na reguliranje zemljišnopravnih pitanja vrlo je raznolika. Ovdje nije riječ o tome da su autori propisa bili nedovoljno upoznati s prirodom vojnokrajiškoga društva i prostora nego o njihovu pokušaju da postojeću situaciju normiraju pravnim terminima kojima su raspolagali.

Početkom 19. stoljeća bila je promijenjena paradigma, te se kod formuliranja Osnovnih krajiških zakona polazilo od drukčijih stanovišta. Iako su i oni, poput Krajiških prava, bili izraz carske volje, intencija njihovih autora je bila da zakoni budu „prikladniji duhu vremena i narodu." Promjena paradigme do koje je došlo u vremenu od nastanka Krajiških prava (1754.) do Osnovnih krajiških zakona (1807.) može se pratiti uspoređujući pravnu terminologiju ta dva akta. U tom su smislu Osnovni krajiški zakoni su mnogo egzaktniji nego Krajiška prava za koja je karakteristična brojnost i raznolikost pojmova od kojih se mnogi uopće više ne javljaju Osnovnim krajiškim zakonima. Treba, međutim, naglastiti da su ta dva pravna akta posve različita po strukturi i usporediva jedino kad je riječ o zemljišnopravnim i nasljednopravnim pitanjima.

Specifičnost Osnovnih krajiških zakona iz 1807. godine je što njihovo treće poglavlje predstavlja kodifikaciju običajnoga prava krajiških zajednica na prostoru Vojne krajine, tj. njima se kodificiraju običajnopravna pravila vezana uz krajišku obitelj - zadrugu. Osnovni krajiški zakoni također kao i Krajiška prava definiraju zemlju krajišnika kao leno Militär-Lehen

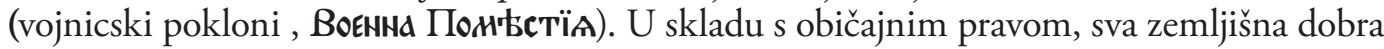
su definirana kao vlasništvo čitave zadruge te podijeljena na baštinu, Stammgut (Koreno Imanje, Kофєнна Дов९d), koja je bila neotuđiva, i tzv. suvišpolje, Ueberland (savishja zemlja, иिБє९лdнAZ), s kojim je zadruga mogla raspolagati. Premda se rabi i pojam Besitzer (Gazda, п९нтАЖАтЕль), iz zakonskih odredbi je bilo jasno da se zadruga smatra kolektivnim vlasnikom zemlje. Baština je bila neotuđiva jer je uz nju bila vezana vojna obveza krajišnika. Za zadrugu se koriste pojmovi Haus-Communion/Hauscommunion (kuchna druxbina/ druxina, Дондшна Оิвчнна) і Gränzhaus (Granicsarska kucha, Г९дннчдфскї̈н Аонz), ili Haus (kucha, A0d1z). Osnovnim krajiškim zakonima tradicionalnu obitelj se i na razini prava uklopilo u vojnokrajiški sustav gdje je vojna obveza bila vezana uz korištenje zemljišta koje je definirano kao Nutzeigenthum (Vlastitost, сОБственность). Osnovnim krajiškim zakonima su definirani izvanobiteljski (u odnosu prema vanjskome sustavu, tj. državi) i unutarobiteljski odnosi te se javljaju pojmovi za kućnoga starješinu Hausvater (Kuchni Stareshina/

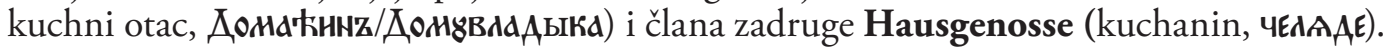

$\mathrm{Na}$ temelju pojmovne analize može se reći da su autori Osnovnih krajiških zakona dosta uspješno izabrali termine na njemačkome jeziku kojim će urediti običajno pravo slavenskoga stanovištva na vojnokrajiškome prostoru. No, slika je ponešto drukčija kad je riječ o terminologiji Krajiških prava. Ona pokazuju nedosljednost i nesigurnost pravne terminologije kad je riječ o obiteljskim, zemljišnim i nasljednim odnosima.

Da bi regulirali postojeće stanje, autori Krajiških prava služe se terminima pripadnim rimskoj pravnoj tradiciji koja je zbog svoje utemeljenosti na principu individualizma bila u osnovi neprikladna za uređenje pravnog položaja krajiških zajednica koje su, neovisno o svome podrijetlu, bile utemeljene na kolektivističkim načelima. Ovdje se prije svega misli na krajiške obitelji - zadruge i na običajno-pravna pravila kojima su se one ravnale. Najizrazitiji je primjer pojam communio bonorum ili gemeinschaftliche Würtschafttreibende koji se koristi kao pojam za zadrugu, odnosno za njene članove. Iz iste logike proizlaze i sljedeći pojmovi: Lehen-Trager, Caput Familiae, Haubt des Hauses, Principal-Lehen-Trager. U tom smislu se pravna rješenja koja se javljaju u Osnovnim krajiškim zakonima, mogu shvatiti kao korektiv Krajiskih prava. 
Prijenos pojmova pripadnih rimskom pravu u druge pravne sustave u svrhu konceptualnog obuhvaćanja nerimskih instituta nije bio neuobičajen - najeklatantniji primjer je institut dvojnog vlasnišstva nad zemljištem koji je oblikovan u srednjem vijeku uz pomoć rimskopravnih pojmova nastalih - dominium utile (koristovno vlasništvo) i dominium directum (vrhovno vlasništvo) - iako takva dvodioba vlasništva u antičkom rimskom pravu nije postojala. ${ }^{27} \mathrm{U}$ tom smislu, kada su pravnici pokušali terminologijom rimskog prava definirati i zadrugu kao običajno-pravni institut koji je proizlazio iz načina života tradicionalnih zajednica na području Vojne krajine, u osnovi nisu činili nešto što nije bilo uobičajeno u praksi obrazovanih pravnika. Kakve je sve posljedice takav pristup mogao imati u konkretnoj pravnoj praksi tek bi trebalo istražiti. Ono što se sa sigurnošću može tvrditi je da se, kako je već navedeno, pedeset godina kasnije od toga odustalo. Mnogo je veći problem što iz Tit. IV. proizlazi da su pravnici implicitno regulirali dva nasljedna uređenja: individualno i kolektivno, karakteristično za zadruge, dok se Osnovnim krajiškim zakonima nedvojbeno preferiraju zadružne imovinske strukture.

\section{Zaključne napomene}

Autori Krajiških prava „transplantirali“ su, barem kad je riječ o normativnoj razini, čitava uređenja temeljnih pravnih grana iz nasljednih zemalja Monarhije u analfabetska krajiška društva s različitim pravnim tradicijama kojima je bilo zajedničko da je njihova svakodnevica dotad uglavnom bila regulirana pravilima običajnog prava. Budući da je riječ o patrijarhalnim zajednicama, karakterizirala ih je neodvojivost moralnih od pravnih načela ${ }^{28}$ i specifična pravna kultura, odnosno pravne kulture.

Otvoreno je pitanje konkretnih reperkusija, tj. susreta individualističkih pravnih principa općeg prava (ius commune) kao recipiranog rimskoga prava i običajno-pravnih pravila krajiških kolektiviteta, koje su pravni principi Krajiških prava imali na život krajiških zajednica.

Najkasnije do početka 18. stoljeća u Vojnoj krajini je postojala neka vrsta paralelnih svjetova koji su se samo djelomično međusobno prožimali - vojnobirokratska hijerarhija koja je trebala osigurati određene interese dvora, prije svega vojne naravi, i krajišnici koji su u mnogim domenama svakodnevnoga života svojih zajednica živjeli kao svijet za sebe.

Cjelovitu sliku o pravnome sustavu u Krajini prije „regulacije“ sredinom 18. stoljeća vrlo je teško oblikovati upravo zbog rasutosti dokumenata - naime, krajiške su zajednice pojedinačno rješavale svoje pravne statuse u dogovoru s vojnokrajiškom hijerarhijom. U taj dio vojnokrajiške pravne povijesti ubrajaju se partikularna prava, privilegije, pojedinačni ugovori, kao i svi propisi koje je donosila vojna hijerarhija, isto kao i pravna praksa koja se oblikovala djelovanjem vojnokrajiških sudova. Također, Krajiškim pravima su zapravo dokinute nekadašnje sudske autonomije krajišnika.

$\mathrm{Na}$ samom kraju rada o Krajiškim pravima u kontekstu centralizacije i modernizacije u Vojnoj krajini, ne bi bilo naodmet spomenuti u kojem bi pravcu mogla krenuti daljnja istraživanja ove problematike. Kao prvo, u navedenom kontekstu bilo bi uputno istražiti u kojoj su mjeri Krajiška prava podudarna sa Vojnim sudskim redom (Militär-Justizordnung), donesenim iste godine. Također, bilo bi interesantno proučiti u kojoj se mjeri može uspoređivati s krajiškom situacijom harmonizacija pravnog sustava koja se istodobno provodila i u

\footnotetext{
7 STEIN, Rimsko pravo i Europa, 72, 73.

28 Georges GURVITCH, Sociologija prava, Sv. II., Zagreb, 1966, 211.
} 
drugim dijelovima države, primjerice „Trgovačkoj provinciji Primorja“ (Litorale Austriaco), u svrhu centralizacije i modernizacije ${ }^{29}$. Konačno, bilo bi nadasve zanimljivo ispitati jesu li Krajiška prava kao svojevrsna probna preteča „u malom“ utjecala na velike potonje kodifikacijske pothvate carice Marije Terezije: znamenitu kaznenopravnu Constitutio criminalis Theresiana iz 1768 g. te građanskopravni Codex Theresianus, koji je kao nacrt kodifikacije objavljen $1776 \mathrm{~g}^{30}$. No prije svega, trebalo bi detaljno proučiti arhivski sačuvanu sudsku praksu u Vojnoj krajini nakon usvajanja Krajiških prava te utvrditi u kojoj su mjeri Militar Gränitz-Rechten carice Marije Terezije doista zaživjeli u krajiškoj svakodnevnici.

\section{$\cos$}

\section{ZUSAMMENFASSUNG}

In diesem Artikel werden die Entstehung, die Struktur und die Bedeutung der Militar Gränitz Rechten aus dem Jahr 1754 analysiert. Das Dokument zählt zu den grundlegenden rechtlichen Normen für die Militärgrenze zur Zeit Maria Theresias. Das Resultat der Analyse zeigt, dass die wichtigste Intention genannter Vorschriften war, das rechtliche System in der Militärgrenze zu unifizieren und zu modernisieren, sowie - so weit wie möglich - mit dem rechtlichen System habsburgischer Erbländer (,....wie in Unseren Erbländern...") in Einklang zu bringen. Die Verfasser der Militar Gränitz Rechten haben - wenigstens auf normativer Ebene - die Regulierung der wichtigsten Teile des Rechtssystems, wie es in den habsburgischen Erbländern bestand, in analfabetische Gesellschaften der Militärgrenze, die sich zu dieser Zeit in ihrem Alltag nach Gewohnheitsrecht richteten, „transplantiert". Besondere Bedeutung hatte dabei ius commune als ein aus dem Alten Rom übernommenes Recht. Trotz ihrer bedeutenden aufklärerischen Bestrebungen waren sich die Verfasser dieser Vorschrift - vor allem um staatliche Interessen bemüht - dessen bewusst, dass die Gesellschaft in der Militärgrenze nicht tabula rasa ist und dass bei Regulierung einzelner rechtlicher Materien lokale Verhältnisse mitberücksichtigt werden müssen. Auf diese Weise werden Voraussetzungen sowohl für die Verflechtung als auch für den Konflikt verschiedener rechtlichen Kulturen im Rahmen der vielfältigen Verhältnisse zwischen dem Zentrum der Monarchie und ihrer Peripherie geschafft.

Schlüsselwörter: Militar Gränitz Rechten, Militärgrenze, Rechtsgeschichte, römisches Recht, Maria Theresia

\section{$\cos$}

\section{Literatura}

BAYER, Vladimir. Kazneno procesno pravo - odabrana poglavlja, knjiga II, Povijesni razvoj kaznenog procesnog prava, Zagreb 1995.

BEUC, Ivan. Povijest institucija državne vlasti Kraljevine Hrvatske, Slavonije i Dalmacije, Zagreb 1985.

BELLOMO, Manlio. L'Europa del diritto comune, Roma 1998.

BUCZYNSKI, Alexander. „Organizacija policije i pravosuđa u Vojnoj krajini“, Povijesni prilozi 13/1994, 94-95.

VAN CAENEGEM, Raoul. European Law in the Past and the Future, Cambridge 2002.

CALASSO, Francesco. Introduzione al diritto commune, Milano 1970.

29 O „Trgovačkoj provinciji Primorja“ (Litorale Austriaco) v. npr. Eva FABER, Litorale Austriaco. Das österreichische und kroatische Küstenland 1700-1780, Trondheim - Graz, 1995.

30 O Codex Theresianus, njegovu nastanku i obilježjima v. Christian NESCHWARA (ed.), Die ältesten Quellen zur Kodifikationsgeschichte des österreichischen ABGB, Wien - Köln - Weimar, 2012, 15-48. 
COING, Helmut. Die ursprüngliche Einheit der europäischen Rechtswissenschaft, Wiesbaden 1968. idem, Europäische Grundlagen des modernen Privatrechts, Opladen 1986.

ČEPULO, Dalibor. „Tradicija i modernizacija: 'iritantnost' Općeg građanskog zakonika u hrvatskom pravnom sustavu“, u: Liber amicorum Nikola Gavella, Zagreb 2007, 3-5.

ČEPULO, Dalibor. Hrvatska pravna povijest u europskom kontekstu, Zagreb 2012.

DE LUCA, Ignaz. Iustitzcodex, Bd. II, Wien 1793, 231-361, dostupno na internetskoj adresi http://books.google.hr/books/about/Iustitzcodex.html

DOMIN PETRUŠEVEČKI, Alfonz (Alphons von Domin-Petrushevecz). Neuere österreichische Rechtsgeschichte, Wien 1869.

FABER, Eva. Litorale Austriaco. Das österreichische und kroatische Küstenland 1700-1780, TrondheimGraz 1995.

FOREGGER, Egmont. Constitutio criminalis Theresiana, Graz 1993.

GURVITCH, Georges. Sociologija prava, Sv. II., Zagreb 1966.

HELLBLING, Ernst C. Grundlegende Strafrechtsquellen der österreichischen Erbländer von Beginn der Neuzeit bis zur Theresiana. Ein Beitrag zur Geschichte des Strafrechts in Österreich, Wien-Köln-Weimar 1996.

HOKE, Rudolf. Österreichische und deutsche Rechtsgeschichte, Wien-Köln-Weimar 1996.

KASER, Karl. Slobodan seljak i vojnik. Povojačenje agrarnog društva u Hrvatsko-slavonskoj Vojnoj krajini (1535.-1881), Sv. I-II., Zagreb 1997.

KAMBIČ, Marko. Recepcija rimskega dednega prava na Slovenskem s posebnim ozirom na dedni red Karla VI., Ljubljana 2007.

KWIATKOWSKI, Ernest v. Constitutio criminalis Theresiana. Ein Beitrag zur theresianischen Reichs- und Rechtsgeschichte, Innsbruck 1904.

LAZANIN, Sanja. Priručnik iz njemačke paleografije, Zagreb 2004.

LONZA, Nella. Pod plaštem pravde, Kaznenopravni sustav Dubrovačke republike u XVIII st., Dubrovnik 1997.

NESCHWARA, Christian (ed.). Die ältesten Quellen zur Kodifikationsgeschichte des österreichischen $A B G B$, Wien - Köln - Weimar, 2012

STEIN, Peter. Rimsko pravo i Europa. Povijest jedne pravne kulture, Zagreb 2007

ŠARKIĆ, Srđan - POPOVIĆ, Dragoljub. Veliki pravni sistemi i kodifikacije, Beograd 2005.

WESENER, Gunter. Einflüsse und Geltung des römisch-gemeinen Rechts in den altösterreichischen Ländern in der Neuzeit (16. bis 18. Jahrhundert), Wien-Köln 1989.

WESENER, Gunter. „Die Rolle des Usus modernus pandectarum im Entwurf des Codex Theresianus. Zur Wirkungsgeschichte des älteren gemeinen Rechts“, u: Gerhard KÖBLER - Hermann NEHLSEN (eds.), Wirkungen europäischer Rechtskultur. Festschrift für Karl Kroeschell zum 70. Geburtstag, München 1995.

WIEACKER, Franz. Privatrechtsgeschichte der Neuzeit, Göttingen 1967. 